\title{
Not With a Bang, But a Whimper: The End of the Archaic in Northeast Texas
}

Maynard B. Cliff

Unknown

Follow this and additional works at: https://scholarworks.sfasu.edu/ita

Part of the American Material Culture Commons, Archaeological Anthropology Commons, Environmental Studies Commons, Other American Studies Commons, Other Arts and Humanities Commons, Other History of Art, Architecture, and Archaeology Commons, and the United States History Commons

Tell us how this article helped you.

This Article is brought to you for free and open access by the Center for Regional Heritage Research at SFA ScholarWorks. It has been accepted for inclusion in Index of Texas Archaeology: Open Access Gray Literature from the Lone Star State by an authorized editor of SFA ScholarWorks. For more information, please contact cdsscholarworks@sfasu.edu. 
Not With a Bang, But a Whimper: The End of the Archaic in Northeast Texas

Creative Commons License

(c) (i) (9)

This work is licensed under a Creative Commons Attribution-NonCommercial 4.0 International License 


\title{
NOT WITH A BANG, BUT A WHIMPER: THE END OF THE ARCHAIC IN NORTHEAST TEXAS
}

\begin{abstract}
Maynard B. Cliff
The Archaic period in Northeast Texas lasted for thousands of years and, if this length of time can be taken as any indication, it was as an extremely successful adaptation to the Holocene environment of North America. Accepting this view, however, begs the question: "why and how did the Archaic period come to an end?"

This paper uses the term "Archaic" to describe a "way of life" (see Story 1990:211), and in this sense, the Archaic period in eastern North America may be seen as a "tradition," characterized by small, band-level societies, marked by an economy based on "hunting, fishing, shell-fishing, and plant-collecting"(Willey 1966:60). It has often been described in the past as a period of post-Pleistocene "settling in," with increasingly intensive utilization of "local" resources. The Archaic is generally recognized by the presence of certain cultural attributes, including "large and broad-bladed dart points and ground- and polished-stone tools and ornaments" (Willey 1966:60). In this regard, Northeast Texas is no different from much of the rest of eastern North America.

The end of the Archaic period is generally marked by the introduction of a number of technological innovations--the bow and arrow, pottery, and agriculture--that are believed to signal a shift in economic adaptations and settlement patterns, to what can be described as a "Neolithic" pattern (although this term is not widely used in North America). In Northeast Texas, the Archaic lifestyle does not seem to have ended with the introduction of a single complex of traits. Instead, the hallmark traits of the post-Archaic period appear to have entered Northeast Texas from different directions over a period of 800 to 1,000 years. The result seems to be a long period in the archaeological record characterized by the gradual addition of new technologies to an Archaic base.
\end{abstract}

In Northeast Texas, the Archaic period is conventionally ended at 200 B.C. This is followed by what is known as the Early Ceramic period, which is generally characterized by the use of Gary dart points, and by the introduction of arrow points and pottery. But these three technological hallmarks marking the end of the Archaic appear to have been introduced into Northeast Texas at separate times, and there is no clear marker for the end of the Archaic lifestyle in this area.

At the present time, it appears that the introduction of Gary points into Northeast Texas precedes the end of the Archaic, as currently dated. Elsewhere, I have suggested that the last part of the Archaic in this area was characterized by a period when Gary dart points were in use prior to the introduction of ceramics (Cliff et al. 1996). For ease, I have applied the term "Terminal" Archaic to this period, recognizing the changes in dart point styles that distinguish it from the previous Late Archaic.

At the Unionville site (4ICS151), in the White Oak Creek area of Northeast Texas, the identification of a "Terminal" Archaic occupation was based on the presence of numerous varieties of Kent and Gary dart points, and was unassociated with ceramics (Cliff et al. 1996). Most of the identifiable dart points or dart point fragments $(n=12,50$ percent) recovered from Area $\mathrm{C}$ of the Unionville site during all phases of the investigations are Kent or Gary points. Specifically, this sample consists of five Kent points (or point fragments), including varieties Phalba (?) and Quinlan; and seven Gary points, including varieties Kaufman, Hobson, Runge, Emory, Kenedy $(\mathrm{n}=2)$, and Alsa. Although no radiometric dates could be associated with the Terminal Archaic occupation in Area $\mathrm{C}$ of the Unionville site, it is felt to probably date sometime between 350 B.C. and A.D. 150 . 
Formative/Early Caddoan remains in the stratigraphic zone overlying the Terminal Archaic occupation were radiometrically dated to cal A.D. 855-1035, while a radiometric date of cal 770-375 B.C. was stratigraphically associated with an Ellis point and underlay a Gary, var. Kemp point in Area B of the site (Cliff and Hunt 1995).

Although Gary and Kent point types are not well dated in Northeast Texas, Story (1990:217-218) has recently reviewed radiocarbon dates associated with Gary points in North Central Texas and noted that they fall between ca. A.D. 1 and A.D. 600 or 700 . She places Kent points on a similar (or slightly earlier) time level on her chronological chart for Southeast Texas (Story 1990:Figure 33). The varieties of Gary and Kent points present in the assemblage from Area C of the Unionville site (Gary, var. Kaufman; Gary, var. Hobson; Gary, var. Runge; Gary, var. Emory; Gary, var. Kenedy; Gary, var. Alsa; Kent, var. Phalba [?]; and Kent, var. Quinlan) were all originally defined by LeRoy Johnson (1962), based on large dart point collections recovered from the Manton Miller site in Delta County and the Yarbrough site in Van Zandt County. Although both of these sites were characterized by mixing of material from several time periods, Johnson suggested that, at the Yarbrough site at least, there were two periods of Gary point utilization: the first (his Period 3) marked by Gary points with long stems and triangular blades (var. Runge) and a continuation of earlier Archaic tool forms; and the second (his Period 4) marked by low frequencies of Williams Plain $(n=6)$ and what he identified as Sanders Plain $(n=12)$ pottery, associated with an increased number of contracting stem dart points, the most important of which were Gary, var. Kaufman and Gary, var. Hobson, as well as Kent, var. Phalba, Kent, var. Quinlan, and Morrill, var. Slocum points (Johnson 1962:213-216; Story 1990:227).

At the Manton Miller site (41DT1) in the Sulphur River basin, Johnson felt confident in the identification of a "more or less pure Gary component without ceramics" that he believed corresponded to his Period 3 at the Yarbrough site (Johnson 1962:267). These remains (from Area A of the site) included the Kaufman, Alsa, Runge, Colfax, Hobson, Emory, and Kemp varieties of Gary points, along with one Kent point, a Morrill, var. San Pedro point, a Yarbrough point, and a Palmillas point (Johnson 1962:Table 4). Johnson apparently believed that the few arrow points $(n=4)$ and ceramic sherds $(n=13)$ from this area were associated with a later occupation in another part of the site (Johnson 1962:267). Johnson's interpretations definitely point towards the existence of a period of time in eastern Texas, prior to the introduction of ceramics, when dart point assemblages were dominated by various forms of contracting-stem Gary dart points, along with straightstemmed Kent and possibly Morrill points. Unfortunately, Johnson's data are equivocal in regard to whether or not any specific varieties of Gary and Kent points are limited to this period. At the Yarbrough site, this aceramic period was associated with Gary, var. Runge points; at the Manton Miller site, however, it was associated with the Kaufman, Alsa, Runge, Colfax, Hobson, Emory, and Kemp varieties of Gary points, and an unspecified variety of Kent point. To further confuse matters, at the Yarbrough site, Johnson associated Gary, vars. Kaufman and Hobson, and Kent, vars. Phalba and Quinlan, with the Early Ceramic period.

1n his overview of Fourche Maline culture in Arkansas (analogous to what is presently defined as the Early Ceramic or Woodland period in Northeast Texas), Schambach (1982:173-177) argues that Gary points are largely diagnostic of that culture, and goes on to define three varieties of Gary point in southwestern Arkansas, using characteristics of stem form, width, and thickness. Schambach's Gary variety is defined as having broad lobate stems with convex edges and rounded bases. He dates it to the "very early or transitional Fourche Maline [or] wholly preceramic components" (Schambach 1982:174), believing it is not present after ca. 400 B.C. Schambach believes his Le Flore variety is contemporaneous with Tchefuncte and early Marksville in the Lower Mississippi valley 
(ca. 400 B.C.-A.D. 200) but occurs prior to the introduction of arrow points. It is distinguished by having narrower, $\mathrm{V}$-shaped stems with pointed bases, in comparison to the Gary variety. Schambach's final variety of Gary point is termed the Camden variety. It is distinguished by being the narrowest variety of Gary point, with blades only slightly wider than the stems, which are similar to those of var. Le Flore, and shoulders which are small or missing entirely. Schambach believes this variety of Gary point is contemporaneous with late Marksville, Troyville, and Baytown in the Lower Mississippi valley (ca. A.D. 200-700) and partially contemporaneous with arrow points (after A.D. 400).

Unfortunately, Schambach's Arkansas data do not appear to be directly applicable to the situation in Northeast Texas. While Schambach identifies three varieties of Gary point in Arkansas, Johnson identifies nine varieties in Texas. Based on comparisons between specimens illustrated by Schambach (1982:Figure 7-6) and Johnson (1962:Figure 4), var. Gary seems to be roughly analogous to vars. Kaufman and Hobson in regard to stem form; var. Le Flore appears to be analogous to vars. Runge and Kenedy, as well as some specimens of var. Kaufman; and var. Camden appears to be analogous to var. Kemp. Nevertheless, it is significant that, like Johnson, Schambach identifies a period, at the end of the Late Archaic and the beginning of the Fourche Maline (or Early Ceramic), of Gary point use prior to the introduction of either pottery or arrow points.

The introduction of ceramics and arrow points seem to be more reasonable markers for defining the end of the Archaic, on the basis of technology. The data we have now indicates that ceramics were introduced into Northeast Texas prior to arrow points (Story 1990:220). In Arkansas, ceramics appear to be present after 400 B.C. (Schambach 1982:Table 7-1). In Oklahoma, Story (1990:222) notes a series of radiocarbon assays suggesting that in some portions of the Ouachita Mountains ceramics were being made in limited amounts as early as 200 B.C. In Northeast Texas, ceramics were introduced between ca. 500 B.C. and 100 B.C. (Story 1990:220).

Despite these early dates for the introduction of ceramics, it is not known how long it took for ceramic manufacture to become widespread or even common. Story (1990:222) emphasizes this problem by noting that the spread of ceramics along the upper Texas coast from Sabine Pass to the Brazos Delta apparently took almost 400 years. Ceramics are abundant at the Hutt site (3HE3), in the Little River area of southwestern Arkansas, which Story (1990:296) suggests may have been occupied as early as A.D. 300 or 400 . To the west, 15 Gary points were reportedly associated with three Marksville sherds (Marksville Stamped, Marksville Incised, and possibly, Churupa Punctated) and a few possible Williams Plain sherds at the Bert Davis site (41HP3) on the South Sulphur River (Story 1990:303). A Marksville period component is also suggested to be present at the Snipes site (41CS8) at Wright Patman Lake, distinguished by the presence of dart points (10 Gary, one Ellis, one Yarbrough, and 10 unclassifiable), "possible Marksville-like sherds," and Williams Plain ceramics (Story 1990:304). The presence of Marksville ceramics at these sites indicates that these components date subsequent to 100 B.C. (cf. Jeter and Williams 1989:127), and also suggests that after that time ceramics were present in low frequencies on many sites within the Sulphur River basin. More recently, deposits dominated by Gary points but lacking ceramics have yielded a series of dates between 1,800-2,300 B.P. (ca. 350 B.C.-A.D. 150) at the Hurricane Hill site (41HP106) at Cooper Lake (Tim Perttula, 1995 personal communication).

The introduction of arrow points (and, presumably, bow and arrow technology) occurred later in the Early Ceramic period. In southeastern Arkansas, arrow points appear after A.D. 400 (Schambach 1982:Table 7-1). In Northeast Texas, they appear between ca. A.D. 500 and A.D. 700 (Story 1990:248). From this, it appears that the technical innovations 
associated with the end of the Archaic in Northeast Texas were staggered. Radiometric dating and stratigraphic data from 41CS151 suggest that Gary points may have come into use in the White Oak Creek area subsequent to 350 B.C. (Cliff et al. 1996) Changes in storage and cooking technology that are presumably associated with the introduction of pottery apparently occurred between 500 B.C. and 100 B.C., and probably became widespread within the Sulphur River basin after A.D. 150. Changes in weaponry (associated with hunting technology and warfare?) associated with the use of the bow and arrow probably date between A.D. 500 and A.D. 700.

The evidence so far suggests that changes in the subsistence economy usually associated with the shift from the Archaic to post-Archaic, were either minimal or nonexistent. Two apparent pits (Features 1 and 2) radiocarbon dated to the Early Ceramic period, $1460 \pm 60$ B.P. (A.D. $595 \pm 50$, corrected) and $2090 \pm 30$ B.P. (or $130 \pm 50$ B.C., corrected), respectively, at 41HP137 at Cooper Lake yielded hickory nut, acorn, wild tubers (possibly the Prairie turnip, Pediomelum or Psoralea sp.), and what may be fragments of cultivated squash or gourd (Fields et al. 1994:12; McGregor 1996:351). Data from later Caddoan sites continues to suggest that intensive cultivation was not practiced until after A.D. 1000 1200 , or even later.

Despite this evidence for continuity, settlement patterns may shift significantly following the end of the Archaic, suggesting other changes in the cultural systems that we simply cannot yet identify. Perttula (1988:18) has noted what appears to be a concentration of Early Ceramic period sites within the Sulphur River basin, although this may be more the result of intensity of research or factors of site preservation rather than the actual presence of an unusually large Early Ceramic population. In regard to modeling settlement patterns during this period, Perttula (1988:18) suggests that "Early Ceramic or Fourche Maline settlements are...represented by villages and hamlets in the floodplains or terraces of larger streams, and by smaller components in the uplands." Many of the sites on which Perttula bases this model, including Snipes at Wright Patman Lake (Jelks 1961) and Tick, Thomas, Hurricane Hill, and Lawson at Cooper Lake (Doehner and Larson 1978; Martin 1996; Perttula 1990), contain middens which are taken as indicating a more sedentary settlement pattern than that of the preceding Archaic period.

The remaining portion of this paper consists of an attempt to model the nature of the cultural changes which appear to have occurred at the end of the Late Archaic, and to present possible reasons for those changes. The basic model for cultural change which will be adopted here is that all such change is basically conservative, and that all innovation is accepted by a culture in an attempt to retain an existing, or traditional, pattern or way of life, not to change that pattern. Real cultural change only comes later, and is usually an unforeseen and unexpected by-product of the initial innovation. Thus, the initial steps toward agriculture in many areas may have been taken to allow the continuation of a hunting and gathering lifestyle under altered circumstances, and not to adopt an entirely new way of life, which is what ultimately happened.

In the present model, it is assumed that there are two independent variables-increasing population and increasing "packing" of population on the landscape. It is generally acknowledged that population density probably reached a peak during the Late Archaic period in Northeast Texas, in comparison to earlier periods, as evidenced by a greater number of Late Archaic sites and by a greater distribution of Late Archaic sites over the landscape (Story 1981:144, 1985:54). At the same time, the decline in group mobility that many researchers have identified with the Late Archaic period is probably due to increased population "packing" during this period. These trends are not confined to Northeast Texas, but characterize the Archaic period throughout the eastern United States (Fagan 1995). 
There can be little doubt that in a society with a hunting and gathering subsistence base, as Archaic societies are believed to have had, increasing population within the group and increased "packing" of groups on the landscape would eventually have led to a decreased resource base and increased subsistence stress for the societies involved. Such stresses, in turn, could have lead to increased inter-group competition, which might have taken the form of increased raiding, either for food or to drive competing groups away from valued resources, and to a heightened impetus for cultural change.

Could these hypothetical stresses, which probably became more critical as the Late Archaic progressed, account for the progressive adoption of the various technological changes that have historically been associated with the end of the Archaic period, specifically pottery, the bow and arrow, and agriculture. As noted above, ceramics may have been introduced into Northeast Texas between ca. 500 B.C. and 100 B.C. (Story 1990:220), but probably became widespread after 100 B.C. The acceptance of pottery by an Archaic society almost certainly would have increased the storage capacity of that society, and brought revolutionary changes in cooking technology (Smith 1986). An increased capacity for longterm storage of some foods would have acted to increase the carrying capacity of a group's territory by allowing more resources to be harvested and stored for future use. Pottery may also have allowed stored food to be more securely hidden from competing groups in a situation where the traditional settlement system did not allow for extended site occupation. Changes in cooking techniques may have led to more intensive exploitation of wild plant resources. For instance, experiments have shown that pottery allows more efficient processing of hickory nuts, one of the most important natural food resources in Northeast Texas, and crushing and boiling has been found to increase by ten times the amount of nutmeat processed in one hour (Taladay et al. 1984). This would also have increased the caloric intake of groups without increasing the resource base or changing the traditional settlement system. Some of these new ways of food preparation may also have increased storability as well (see, for example, the description of the preparation and storage of hickory-nut oil and acom oil in Swanton [1946:366]).

The next technological innovation in Northeast Texas appears to have been the bow and arrow, which apparently was introduced between approximately A.D. 500 and 700 (Story $1990: 248$ ). It is generally assumed that the introduction of the bow and arrow would have brought with it increased efficiency in hunting at an individual level, and increased advantages in inter-group conflict at the group level. More efficient hunting would presumably have been more productive in terms of caloric intake versus the expenditure of time, and supported the retention of traditional hunting activities in the face of a decreased resource base. At the same time, improved defensive abilities during times of increased inter-group conflict would have allowed the retention of a traditional small group size in the face of increased pressure from other groups. John Blitz (1988) has, in fact, suggested that the rapid spread of the bow and arrow across the southeastern United States was primarily due to its advantages as a weapon in competition between sociopolitical groups, rather than pressure to increase hunting capability.

The last technological change generally perceived to accompany the end of the Archaic lifestyle was the development of some form of agriculture. As noted above, intensive subsistence agriculture may have come late to Northeast Texas, possibly post-dating A.D. 1000. The early dates for possible cultivated squash or gourd at Cooper Lake suggest either that the intensive use of early cultivated foods lagged a millenium behind their availability, or that early cultivars were introduced into Northeast Texas as part of the revolution in container and storage technology associated with pottery, and not as food plants at all. In this regard, the similarity in the suggested dates for the spread of early pottery in Northeast Texas (100 B.C.-A.D. 400) and the dates for early cultivated squash or gourds at Cooper Lake (130 B.C.-A.D. 595) is very suggestive. Thus, the initial spread of agriculture 
(perhaps horticulture would be a better term) in Northeast Texas may have been linked to the production of storage and transport containers (thus solving one of the main problems with pottery - its non-portability), and only a millenium later were these techniques adapted to the production of new plant foods. Certainly, when subsistence agriculture was adopted in Northeast Texas, it also would have allowed increased control and predictability of food production within a decreasing resource base.

In returning to the theme of this paper, it should now be clear that most, if not all, of the technological changes associated with the end of the Archaic lifestyle in Northeast Texas, did in fact enter Northeast Texas after the end of the Archaic period, during the period we now identify as the Early Ceramic. Adding to this confusion is the fact that the one trait that may actually predate the Early Ceramic is the presence of pottery. In fact, it is very probable that the so-called Early Ceramic period in Northeast Texas was fully Archaic in lifestyle and tradition, and represents a period of change and modification to the Archaic tradition under the combined pressures of increasing within-group populations, and increasing between-group "packing."

\section{Acknowledgments}

The author would like to thank Mr. Duane Peter and Geo-Marine, Inc., of Plano, Texas, for supporting the preparation of this paper. Much of the data on which this paper is based has been collected by projects supported by the U.S. government. Most recently, research at Cooper Lake and at the White Oak Creek Wildlife Management Area on the Sulphur River was supported and funded by the U.S. Army Corps of Engineers, Fort Worth District, P.O. Box 17300, Fort Worth, Texas 76102-0300.

\section{References Cited}

Blitz, J.

1988 Adoption of the Bow in Prehistoric North America. North American Archaeologist 9(2):123-145.

Cliff, M. B., M. M. Green, S. M. Hunt, D. Shanabrook, and D. E. Peter

1996 Excavations in Area $C$ of the Unionville Site (41CS151), White Oak Creek Mitigation Area (WOCMA), Cass County, Texas. White Oak Creek Mitigation Area Archeological Technical Series, Report of Investigations No. 4. Geo-Marine, Inc., Plano, Texas.

Cliff, M. B. and S. M. Hunt

1995 Cultural Resources Testing of Three Sites within the Moist Soils Management Area (MSMA) of the White Oak Creek Mitigation Area(WOCMA), Cass County, Texas. White Oak Creek Mitigation Area Archeological Technical Series, Report of Investigations No. 3. Geo-Marine, Inc., Plano, Texas.

Doehner, K. and R. E. Larson

1978 Archaeological Research at Proposed Cooper Lake, Northeast Texas, 1974-1975. Research Report No, 108. Archaeology Research Program, Southern Methodist University, Dallas.

Fagan, B. M.

1995 Ancient North America: The Archaeology of a Continent. 2nd edition. Thames and Hudson, New York. 
Fields, R. C., E. F. Gadus, L. W. Klement, and K. M. Gardner

1994 Excavations at the Spider Knoll Site, Cooper Lake Project, Delta County, Texas. Reports of Investigations No. 96. Prewitt and Associates, Inc., Austin.

Jelks, E. B.

1961 Excavations at Texarkana Reservoir, Sulphur River, Northeastern Texas. River Basin Survey Papers No. 21, Bulletin No. 179. Bureau of American Ethnology, Smithsonian Institution, Washington, D.C.

Jeter, M. D. and G. I. Williams, Jr.

1989 Ceramic-Using Cultures, 600 B.C.-A.D. 700. In Archeology and Bioarcheology of the Lower Mississippi Valley and Trans-Mississippi South in Arkansas and Louisiana, by M. D. Jeter, J. C. Rose, G. I. Williams, Jr., and A. M. Harmon, pp. 111-170. Research Series No. 37. Arkansas Archeological Survey, Fayetteville.

Johnson, L., Jr.

1962 The Yarbrough and Miller Sites of Northeastern Texas, with a Preliminary Definition of the LaHarpe Aspect. Bulletin of the Texas Archeological Society 32:141-284.

McGregor, D. E.

1996 Archaeological Investigations at 41HP137. In Archaeological Investigations at Cooper Lake, Delivery Order Numbers 2, 3, \& 4, 1987, by D. E. McGregor, M. M. Green, D. H. Jurney, W. A. Martin, R. W. Moir, and J. W. Saunders, pp. 341-361. 2 Vols. Archaeology Research Program, Department of Anthropology, Southern Methodist University, Dallas.

Martin, W. A.

1996 Archaeological Investigations at 41HP78: The Lawson Site. In Archaeological Investigations at Cooper Lake, Delivery Order Numbers 2, 3, \& 4, 1987, by D. E. McGregor, M. M. Green, D. H. Jurney, W. A. Martin, R. W. Moir, and J. W. Saunders, pp. 363-428. 2 Vols. Archaeology Research Program, Department of Anthropology, Southern Methodist University, Dallas.

Perttula, T. K.

1988 Cultural Setting. In Test Excavations at Sites 41BW/82 and 41BW183, Red River Army Depot, Bowie County, Texas, edited by M. B. Cliff and D. E. Peter, pp. 1125. RRAD/LSAAP Archeological Technical Series, Report of Investigations, No. 1. Geo-Marine, Inc., Plano, Texas.

1990 The Hurricane Hill Site (41HPIO6): Excavations at a Early Ceramic-Caddoan Settlement at Cooper Lake, Hopkins County, Texas. Review Draft. Contributions in Archaeology No. 9. Institute of Applied Sciences, University of North Texas, Denton.

Schambach, F. F.

1982 An Outline of Fourche Maline Culture in Southwest Arkansas. In Arkansas Archeology in Review, edited by N. L. Trubowitz and M. D. Jeter, pp. 132-197. Research Series No. 15. Arkansas Archeological Survey, Fayetteville. 
Smith, B. D.

1986 The Archaeology of the Southeastern United States: From Dalton to de Soto, 10,500-500 B.P. In Advances in World Archaeology, Volume 5, 1986, edited by F. Wendorf and A. E. Close, pp. 1-92. Academic Press, New York.

Story, D. A.

1981 An Overview of the Archacology of East Texas. Plains Anthropologist 26(92):135158.

1985 Adaptive Strategies of Archaic Cultures of the West Gulf Coastal Plain. In Prehistoric Food Production in North America, edited by R. I. Ford, pp. 19-56. Anthropological Papers No. 75. Museum of Anthropology, University of Michigan, Ann Arbor.

1990 Cultural History of the Native Americans. In The Archeology and Bioarcheology of the Gulf Coastal Plain, by D. A. Story, J. A. Guy, B. A. Burnett, M. D. Freeman, J. C. Rose, D. G. Steele, B. W. Olive, and K. J. Reinhard, pp. 163366. 2 Vols. Research Series No. 38. Arkansas Archeological Survey, Fayetteville.

Swanton, J. R.

1946 The Indians of the Southeastern United States. Bulletin 137. Bureau of American Ethnology, Smithsonian Institution, Washington, D. C.

Taladay, L, D. R. Keller, and P. J. Munson

1984 Hickory Nuts, Walnuts, Butternuts, and Hazelnuts: Observations and Experiments Relevant to Their Aboriginal Exploitation in Eastern North American. In Experiments and Observations on Aboriginal Wild Plant Food Utilization in Eastern North America, edited by P. J. Munson, pp. 338-359. Prehistoric Research Series, vol. 6, no. 2. Indiana Historical Society, Indianapolis.

Willey, G. R.

1966 An Introduction to American Archaeology, Volume One: North and Middle America. Prentice-Hall Inc., Englewood Cliffs, New Jersey. 